Oda Wischmeyer

\title{
Ego-documents on religious experiences in Paul's Letters: 2 Corinthians 12 and related texts
}

\begin{abstract}
This article investigates the earliest Pauline text that gives account of an individual revelation and reports on personal religious experience in this field: 2 Corinthians 12:1-10. Paul is the only person from the first decades of the Christ-confessing movement who wrote ego-documents (first person reports) that are embedded in his letters to several communities and individuals. These texts serve predominantly the polemical dispute with opponents in the newly founded communities of Christ-confessors. Some of these texts are very brief narratives of interior religious experiences Paul had in earlier stages of his life. In 2 Corinthians 12:1-10 he reports on visions and revelations (hórasis and apokálypsis), on one or two raptures (harpagmós/raptus) and in contrast on an audition, on a lógion kyriou that he understands as committing him to a life of weakness and disease even though he has urgently prayed for recovery. Though Paul uses his life and his religious experiences as a religious and moral example in this text, the text also opens up a window into his personal religious world that deserves special attention. Beyond its actual setting within Corinthian conflicts, 2 Corinthians 12 is an outstanding example of the hybrid character of Pauline religious experience: the text is situated at the interface of concepts of Ancient Judaism (especially apocalypticism, martyrdom, and the figure of Satan), pagan healing-oracles (Asclepius), individual prayer that is shaped by a formula close to Jesus' prayer in Gethsemane, and the Early Christian concept of the heavenly Christ Kýrios. Beyond that, the function of the text within the broader argument is of particular interest: Paul does not use his apokálypsis for demonstrating the strength and authority of his unique religious expertise or for deepening the religious imagination of the communities, but for the defense and the interpretation of the physical weakness of his person by referring to a particular lógion kyriou that is transmitted only in 2 Corinthians. Thereby he provides his addressees an insight into his personal encounter with the heavenly kýrios and at the same time clarifies that religious communication with the kýrios neither means personal glory nor automatically leads to health, power and success. All in all the text works as a counter-revelation and expresses how cautious Paul is of using his
\end{abstract}

Ә Open Access. (C) 2020 Oda Wischmeyer, published by De Gruyter. (cc) BY-NC-ND This work is licensed under a Creative Commons Attribution-NonCommercial-NoDerivatives 4.0 International License.

https://doi.org/10.1515/9783110557596-010 
personal religious experiences, i.e. revelations, for what he calls boasting (kauchāsthai). The whole personal narrative is directed polemically against those charismatic missionaries who Paul names "hyper-apostles". In contrast, he interprets his disease as the actual revelation of the cháris and the dýnamis of the kýrios. The focus is not on the demonstration of Paul's access to the heavenly world, but on the explanation of his weak physical condition as gift (cháris) of the heavenly Christ and thereby on a religious interpretation of the physical condition of his body. His body is interpreted as a place of revelation.

\section{New Testament Studies; Paul and the different aspects of the importance of his individual religious experiences}

When I received the invitation for the conference on "Lived Ancient Religion": Leaving the (disciplinary) comfort zone - Lived Ancient Religion AD 1 to 800, I wondered whether and how a New Testament scholar could contribute under the fashionable, but provoking and somehow threatening heading of "Leaving the disciplinary comfort zone". New Testament scholarship is committed to the interpretation of the canonical collection of Early Christian texts in their Greco-Roman and Ancient Jewish contexts and to the study of the history of their reception. New Testament scholars also investigate that part of the Early Christian literature of roughly the first two or three centuries $\mathrm{CE}$, that is known and collected under the term "NT apocrypha": texts of different genres that follow up and imitate viz. develop the New Testament literary genres. Nevertheless we feel bound to our discipline and to the discussion of those particular subjects for exegetical debate that have arisen and still arise from the New Testament texts themselves. The extent of our canon is limited and the texts have been interpreted since about $150 \mathrm{CE} .^{1}$ There is no letter and no word in this collection of texts that has not been under discussion countless times, and there is no option for a scholar's choosing of one hypothesis out of others without becoming associated with one or another New Testament "school" or "wing". Therefore, it can be disputed whether New Testament studies are a real "comfort zone"; but the fact that New Testament scholars do work and argue within a specific "zone" -

1 As far as we know the first commentary on a NT book was written by the Gnostic theologian Herakleon on the Gospel of John (about $150 \mathrm{CE}$ ). 
or perhaps better, that a New Testament scholar is a member of a highly specialized and at least partly closed academic "discussion-room of one's own" that fosters its own agenda - cannot be denied.

It is the canonical status of our specific literature that causes this particular situation. Even if we try to interpret our texts without paying any attention to their authoritative status past or present, we have to deal with the amount of learned literature which is the result of that specific status of "our" texts and which we should take seriously as long as we intend to follow the rules of good academic practice of the discipline. In this respect, it is something of a challenge to leave the boundaries of the New Testament scholarship and to navigate in the vast ocean of the history of Greco-Roman religion where "our" texts are not the focus and our interpretative battles and differences so far remain unknown or, at least, less important.

As is generally known, however, some generations ago the situation was quite different from what I have briefly outlined here. The scholars of the so called Religionsgeschichtliche Schule, professors from different faculties and fields of research of the University of Gottingen around 1890/1900, read the texts that later on would be collected in the "New Testament" in their "pagan" environment - especially against the backdrop of the so called mystery religion(s), Gnosticism and religious syncretism as well as of different ecstatic and pneumatic phenomena and movements. But so called Gnosticism is no longer understood as a pre-Christian movement and scholars especially of the two last generations have discovered more in depth the world of Ancient Jewish texts as "parallel text worlds" in comparison with the New Testament text collection. The category "Jewish texts" covers the Septuagint, Philo of Alexandria and Josephus as well as a large number of the amount of apocalyptic, didactic, sapiential and narrative pseudepigraphic texts and the fragments of the Jewish-Hellenistic authors besides the Septuagint. Still in the focus of contemporary scholarship is the exciting library of the Dead Sea Scrolls that have generated their own specialized scholarship. This vast and variegated literature is understood to be the original background of Paul, whom we know as the first Christ-confessing author. Since at least the last fifty years the scholarly focus is no longer on the embeddedness of the New Testament texts in their primarily "pagan" religious environment, but on the relation between Ancient Judaism and the origin of what later on was labelled as Ancient Christianity. In this wave of reconstructing the multifaceted world of Ancient Judaism and respectively Jewishness (recently Sänger 2017), especially Paul was re-interpreted as a Jewish religious agent or a Jewish thinker, and scholars have lengthily debated about the best way of classifying Paul's 
Judaism in the tableau of Jewish hairéseis, as Josephus phrases it, or in a less classifying way, in the context of Jewish texts and their textual communities of the time before the first Jewish war. The debates on "Paul within Judaism" still go on and attract the interest of most of Pauline scholarship so that scholars have paid less attention to the issue of Paul and ancient religion(s).

Interestingly enough, there is also a focus on Paul's relationship with popular philosophy, especially fostered by such leading scholars as Hans Dieter Betz (Betz 1978) and Abraham Malherbe (Malherbe 2006; Downing 1998), and on Paul and Stoic and middle Platonic philosophy, inaugurated by the studies of Troels Engberg-Pedersen (Engberg-Pedersen 2000; 2010) and Stanley Stowers. ${ }^{2}$ A second major issue is the emperor cult, with its specific combination of political and religious dimensions, in regard to Paul: recently labelled under the topic of "Paul and Empire" (Horsley 1997) or "Paul and Politics" (Horsley 2000) - the titles of two seminal collections of essays, edited by Richard Horsley. ${ }^{3}$ In comparison with these fields of research no large-scale initiative has been launched so far with the aim to revitalize or even to improve the approach from the side of the pagan - or perhaps better, the common - religious environment of Paul's addressees in Asia Minor and Greece. ${ }^{4}$ My paper aims at pointing especially to this aspect of Paul's religious mission in his encounters both with the Jewish religion from which he came (circumcised) and with "pagan" (éthnē) religion as the field to which he felt committed as agent of Jesus Christ kyrios. The majority of Paul's addressees had shared the cult-practices of the cities in which they lived before Paul converted them to members of the Christ-confessing new associations, named ekklēsíai (1 Thessalonians 1:9s; 1 Corinthians 12:1-3; Galatians 4:8-10); Paul himself, as a diaspora Jew born in Tarsus and educated as Pharisee, was also acquainted with "pagan" cults and their religious culture. The newly established Christ-confessing communities existed in an uncertain religious and legal status between the variety of pagan cults, Jewish synagogues and those small Early Christian institutions that had already been founded by the first apostles in

2 For an introduction to the current state of scholarship see: Stowers 2015; van Kooten, Wischmeyer and Wright 2015; Wischmeyer 2018.

3 Other major contributions by Neil Elliott, and John Dominic Crossan. Labelled as a "fresh" perspective on Paul by N.T. Wright in his 2000 Manson Memorial Lecture.

4 But see the major contributions by Hans Dieter Betz and Hans-Josef Klauck: Betz 1990-2009; Klauck 2003. There is also a lively scholarly debate on the issue of how to classify the Jesus movement and the early ekklesíai in the context of cultic, religious, and ethnic associations. Special studies touch the religious scene of Corinth, Thessaloniki, Philippi and Galatia in the 1st century CE. 
Palestine and Syria. As far as we know, the Jesus-literature of the gospels was not yet written, and only some oral traditional materials about Jesus' preaching and healing and about his death and resurrection circulated among the communities. The recently converted Christ-confessors had basically loosened or even cut off the public and private participation (1 Cor 8) in the Greco-Roman cults and so far had no deep knowledge of the Jewish imaginative religious background. Paul had to build up their discrete religious culture and knowledge both practical and theoretical - as well as a particular exterior (house churches) and interior religious space (imaginations). The same was true for former Jews or God-fearers who were attracted by the Pauline ekklessiai. They too had lost parts of their Jewish religious heritage, especially their connection to the Temple cult, perhaps also to local synagogues, and to Jewish ritual and daily religious life. Be they former pagans or former Jews, each of the converts had to grapple with a massive loss of the religious environment they were brought up in and used to, and they had to conceptualize a new religious framework for their assemblies in their house churches and for their individual religious and social lives in their homes (aspects of "domestic religion").

Since the topic of "The Pauline communities and Pauline religious advice in their overall religious context" has not yet been discussed sufficiently, ${ }^{6}$ I shall concentrate on Paul himself as we know him from his letters and on how he reacts to the situation of his communities. One of Paul's resources to build up and to strengthen the domestic religion and the inner religious ideas and perceptions of the members of the Christ-confessing communities, was his personal religious experience - which could work as an example that should be communicated to the ekklēsiai. ${ }^{7}$

At this point of my essay, I shall clarify in advance some overall aspects of the person and the religious agency of Paul in order to better connect the Pauline texts with the theme of religious experience. In the invitational text of the conference, the main issues of what we should investigate are outlined in detail. The concept of "lived ancient religion" has not been applied so far to Pauline texts and cannot be simply tried out or applied here. However, in so far

5 This term is necessary for describing Jewish religion and Early Christian house church cult (1 Cor 11:17-34).

6 Exegetical literature is focused on the institutional status of the ekklēsíai, not so much on the religious traditions, expectations and needs of their members.

7 We don't have a recent monograph on "Paul and Religion" that matches the standards of today's research in Greco-Roman religion. In contrast see the monographs of the „Religionsgeschichtliche Schule“: R. Reitzenstein, A. Deißmann, J. Weiß, W. Bousset, W. Wrede. 
as the concept includes religious experience, it can help understand Paul and his communication with his communities. The look at the Pauline texts also broadens the general world of texts of religious studies by integrating those from the allegedly independent worlds of Ancient Jewish and Early Christian texts into the text-corpus of Greco-Roman religious studies. Furthermore, we are able to reconstruct at least aspects of Paul's "religious experience": in the conference-paper defined "as a product of a wide range of sensory stimuli, affects and inner feelings that are articulated by subjects ... as religious experience". This endeavor can help us to attach a higher priority to Paul's religious experience than has been paid to date in current Pauline studies as I have already mentioned. ${ }^{8}$

The starting point for our endeavor are the first person reports on individual religious experiences by Paul, written down in his letters to his communities, although these texts are literarily and argumentatively shaped by apologetic, polemical and exhortative intentions. Paul refers four times to visions or to similar encounters with the heavenly world. ${ }^{9}$ He was the first and for a considerable space of time the only person among the leading figures of Earliest Christianity - Peter, James the brother of Jesus and some of the "Twelve" - who did not limit himself to oral preaching, but wrote letters under his own name and in his own responsibility, and at the same time argued by using predominantly not Jesus, but his own person as an example of moral and religious instruction. He was quite aware of his persona and discussed his egō in different theoretical and biographical contexts without ever questioning that not only his message and his instructions, but also his person was of highest importance for his communities and in particular for his epistolary audience. ${ }^{10}$ Primarily, his way of arguing by means of his personal conduct of life and of his external and inner religious biography was a matter of claiming authority within, against or even above the given authority of the leaders of the communities of Christconfessors of the first generation (about 30-60 CE). As we learn from his letters, but also from some passages of the Acts of the Apostles, Paul's person was highly controversial not only in the environment of contemporary diaspora synagogues, but Paul was also an object of dispute between different religious parties within the Christ-confessing communities on the one hand and between rivalling missionaries or newcomers in the cities and regions where he had

8 See the very short introduction by Lang 2013. This paragraph gives a clear picture of the marginal position of the topic in recent Pauline scholarship.

9 Gal 1; 1 Cor 9; 1 Cor 15; 2 Cor 12. Scholars point also to 2 Cor 4:6. Monographs: Heininger 1996; Meier 1998. Heath 2013 focusses on 2 Cor 2:14-7:4, especially on 3:18.

102 Cor 10:10 on the impact of his letters in contrast to his preaching power. 
established communities on the other. So, Paul had to do a lot of self-explaining and self-defense in his letters.

There was however another, still more important reason for his constant reference to his own thoughts and personal experiences. As I have already mentioned, the new religious movement of the Christ-confessing and Christ-believing ${ }^{11}$ com- $^{-}$ munities, which Paul had established around $50 \mathrm{CE}$ as ekklēsíai in several main cities of western Asia Minor and Greece, had a strong need not only of institutional, doctrinal and moral advice, but also of imaginative and emotional support from him whom they thought of not so much as their teacher, but as their founding father. ${ }^{12}$ That the communities themselves called for guidance is demonstrated by the dense communication between Paul and their leading figures. ${ }^{13}$ Paul himself was very much aware of his lasting responsibility for the members of the communities and of the importance of their personal and emotional guidance, as is demonstrated by his letters. ${ }^{14}$ In other words, the letters are documents not only of doctrinal, moral and institutional instruction, but also of constant efforts to build up, to strengthen and to enhance the personal and emotional communication, as well as the attachment, between his person and the addressees. In this regard, his letters are personal documents.

We have also to take into consideration that the earliest Christ-confessing communities which were already known by the Roman authorities ${ }^{15}$ (who named them christianoi, ${ }^{16}$ whilst Paul himself does not use this label ${ }^{17}$ ) were constituted so to speak from out of the blue by Paul. These brand-new religious associations (Öhler 2016), though having something like a religious club or association status and club or association rules from the outset and thereby some kind of inner structure and stability, nevertheless stood on extremely shaky ground. They were solely grounded in Paul's message and in his organizational genius and persuasive power. Their relations, neither to the local synagogues nor to the different pagan religious associations, were not sorted out and their status in relation to the local authorities remained unclear. Paul took residence

11 Romans 10:9: If you confess with your mouth "kýrion Jēsoūn" and believe in your heart that God raised him from the dead, you shall be saved.

12 Paul as father: Paynter 2017, 245-249.

13 Best example: 1 Corinthians and Corinthian correspondence as a whole. Introductory work: Bieringer 1996.

14 Scholars classify some of his letters as "friendship"-letters: Theissen 2007, 116.

15 According to Galatians 1:13.23 the Christ-confessing community of Damascus was known by the religious authorities in Jerusalem very early (already at about $33 \mathrm{CE}$ ).

16 Acts 11:26. That means that Christianoí lived in an unclear legal status and always were in need of mental, emotional and - as far as possible - legal or political (Romans 13) support. 17 He speaks of en Christō eìnai. 
in the communities only for a short period of time, then left, and afterwards the new communities were left to themselves or to other missionaries, like Apollos in Corinth, whose status remained unclear - at least in Paul's perspective. Further instruction, encouragement and personal proofs of the truth of Paul's message were urgently needed, as the problems in Corinth (1 Corinthians 1:12 ${ }^{18}$ ) and the array of questions that are asked by the Corinthians themselves demonstrate: questions about marriage, food sacrificed to idols, women's behavior during the services, the Lord's supper, spiritual gifts, leading positions in the communities, and resurrection of the dead.

Paul was convinced that the religious experience of the Spirit worked in addition to his own support and affection. Accordingly he pointed to the multifold manifestations of ecstatic pneumatic power and abilities like healing and performing miracles as well as speaking in tongues and prophesying in the assemblies of the christianoí. In his view not he himself, but these "gift(s) of the Spirit" are the real foundation and the backbone of the communities. In his letter to the Galatians, Paul argues that the appearance of charísmata and pneumatiká during the community-services were the most convincing expression and confirmation of the power and the truth of his initial preaching and of the community's belief in his message (Galatians 3:2). In 1 Corinthians 12-14 he draws an authentic and vivid portrait of the community's assembly for service which - besides singing hymns and psalms and preaching - is characterized by multifold charismatic or pneumatic activities such as prophetic speech and speaking in tongues (glōssolalía) (Treu 2018).

But evidently the members of the communities needed more than their own pneumatic experience and more than Paul's report on his personal experience. This becomes clear when we read 1 Corinthians 15:1-7. Here Paul in a fundamental way appeals to what later on will be called "apostolic tradition". Not only tradition as such comes in, but Paul brings his own person into connection with this tradition. One may ask whether what Paul offered matched the needs of his communities, or whether Paul actually understood what the communities missed. But as far as we see, Paul uses reference to "Kephas and to the Twelve" and general recourse to the "tradition" (V.3) as the first and most convincing tool in the whole argument of chapter 15. Anyway, his reaction was far from picturing his own experience extensively and in detail, when he repeated what he called to euaggélion, i.e. the message of Jesus Christ, in firm relation to the tradition, though also combined with reference to his own person and responsibility

18 Problems that are addressed by Paul: quarrel and strife. Paul mentions also problems in regard to sexual behavior and to legal questions. 
and his own religious experience. 1 Corinthians $15: 3-8$ is the key text for this kind of argument which is characteristic for Paul and for his kind of preaching:

3 For I handed on to you as of first importance what I in turn had received: that Christ died for our sins in accordance with the scriptures, 4 and that he was buried, and that he was raised on the third day in accordance with the scriptures, 5 and that he appeared $(\overline{o p h t h e})^{19}$ to Cephas, then to the twelve. 6 Then he appeared to more than five hundred brothers and sisters at one time, most of whom are still alive, though some have died. 7 Then he appeared to James, then to all the apostles. 8 Last of all, as to one untimely born, he appeared also to $m e^{20}$

By that Paul puts himself into the line of tradition of the resurrection witnesses. Scholars disagree in their analysis of the text (Zeller 2010, 460-474): how far delivers the text tradition, and at which point does Paul extend the original tradition by adding more witnesses and at last inscribing himself in person in that list? This question cannot be discussed here sufficiently. What matters in our context is that this document is the expression of Paul's claim for apostolic authority in the context of the kind of apostolic authority that is already established in the communities. 1 Corinthians 15:8 does not provide insight into the religious experience Paul had, but only serves to demonstrate his absolute trustworthiness and his traditional apostolic authority.

Already earlier in the first letter to the Corinthians, Paul refers to the same qualities, i.e. to his apostolic status, by asking a series of rhetorical questions:

Am I not free? Am I not an apostle? Have I not seen (heōraka) ${ }^{21}$ Jesus our Lord? Are you not my work in the Lord?

(1 Corinthians 9:1) 22

Paul uses the same verb: horáō (see), but a differently addressed object: Jēsoūn Kýrion instead of Christós. ${ }^{23}$ No further detail of this religious experience is reported by Paul. Astonishingly enough we encounter the same extreme brevitas in his letter to the Galatians 1:16s.:

15 But when God, who had set me apart before I was born and called me through his grace, was pleased 16 to reveal his Son to me, so that I might proclaim him among the Gentiles, I did not confer with any human being, nor did I go up to Jerusalem to those

19 Present time: horáō.

20 NRSV.

21 Present time: horaō.

22 NRSV.

23 Christós probably was part of the traditional formula. Jesus is the more personal name that points to a face-to-face encounter. 
who were already apostles before me, but I went away at once into Arabia, and afterwards I returned to Damascus.

Galatians 1:10-2:14 (or 2:21) ${ }^{24}$ is the most important of Paul's autobiographical texts, something like his curriculum vitae, and thereby the bedrock of Pauline chronology and biography. But even in this lengthy text Paul is absolutely silent about any detail of his religious experience. What counts is the vocation by God and the exclusive mandate God has given him even before his birth. In other words, also Galatians 1 is about authority and legitimacy, not about religious experience - though we may imagine that Paul's addressees longed exactly for that.

To sum up so far, there are two main exterior reasons that urge Paul to refer to his personal religious experience: first, the constant questioning of his authority and legitimacy, and second, the communities' demand for religious support, i.e. for personally approved pictures of the heavenly world of the kýrios whose reign Paul proclaimed and of their own destiny (1 Cor 15). ${ }^{25}$ Paul however, reacts most restrainedly against these challenges, many times pointing to his apostleship, but only three times (!) to his experiences with the kýrios. He refuses to reveal any details of his personal experiences with Christ and nowhere draws a picture of the heavenly world in the contexts of his own experiences.

\section{Corinthians 12:1-10: a literary stylized report on Paul's religious experience}

But there is at least one exception. Among the numerous more or less independent text-units which build up the argument of Paul's letters we find one text in which we come closest to how Paul himself dealt with what we may call personal religion or the expression of individual religious experience: 2 Corinthians 12: 1-10. It is this one particular text that is suited for drawing together all the threads from Ancient Jewish texts, Early Christian texts ${ }^{26}$ and the vast variety of so to speak pagan religious documents, materials and artifacts, in order to interpret Paul's personal religious world from different angles. Besides its significance

24 Scholars differ in their analysis of chapter 2: What is the extent of his biographical retrospection, and when does he start his current argument?

25 In 2 Corinthians 10-13 Paul explores that topic in a polemical way.

26 It is only texts we have from Jewish and Early Christian communities of the first two centuries $\mathrm{CE}$. 
for the subject of "Paul and Greco-Roman religion", the report may be of particular interest for scholars engaged in research about individual religious experiences beyond the boundaries of Ancient Judaism, paganism resp. Greco-Roman religion and Early Christianity, because Paul is a very well documented historical figure of the 1st century CE whose personal religious reports are unparalleled, at least in Earliest Christianity:

2 Corinthians 12:1 It is necessary to boast; nothing is to be gained by it, but I will go on to visions and revelations (optasías kai apokalýpseis kyriou) of the Lord. 2 I know a person in Christ who fourteen years ago was caught up (harpagénta) to the third heaven (tritou ouranoū) - whether in the body (sōmati) or out of the body I do not know; God knows. 3 And I know that such a person - whether in the body or out of the body I do not know; God knows - 4 was caught up into Paradise (parádeison) and heard things that are not to be told (arrēta rēmata), that no mortal is permitted to repeat. 5 On behalf of such a one I will boast, but on my own behalf I will not boast, except of my weaknesses. 6 But if I wish to boast, I will not be a fool, for I will be speaking the truth. But I refrain from it, so that no one may think better of me than what is seen in me or heard from me, 7 even considering the exceptional character of the revelations (tē hyperbolè tōn apokalýpseōn). Therefore, to keep me from being too elated, a thorn was given me in the flesh, a messenger of Satan (ággelos Satanā) to torment (kolaphídzō, 'to buffet', to strike (Liddell-Scott 971)) me, to keep me from being too elated. 8 Three times I appealed to the Lord about this, that it would leave me, 9 but he said to me, 'My grace (cháris) is sufficient for you, for power (dýnamis) is made perfect in weakness.' So, I will boast all the more gladly of my weaknesses, so that the power of Christ may dwell in me. 10 Therefore I am content with weaknesses, insults, hardships, persecutions, and calamities for the sake of Christ; for whenever I am weak, then I am strong. ${ }^{27}$

The text is characterized by some peculiarities and, all in all, by a remarkable lack of clarity which seems to be intended. In light of the carefully molded composition not only of 2 Corinthians 12:1-10, but also of the context (chapters 10-13), we have to suppose that Paul plays with this ambiguity, using it as a stylistic device. He initiates his text - nolens volens as he says - by announcing a recital of his personal visions and revelations of the heavenly kýrios, but we can suppose that his report left the addressees disappointed, because he immediately drops the enumeration of revelations. Instead of narrating about his heavenly adventures he writes in an obscure way about a third person, who nevertheless seems to be Paul as the exact dating of the revelation may indicate. ${ }^{28}$ All in all,

27 NRSV.

28 Thrall 2000, 782. Of specific interest is that Paul points back to an experience that occurred to him about fourteen years ago (12:2). This exact biographical note makes clear that the experience was very important and an unforgettable one and that there have not been more important visions afterwards. 
verses 1-5 are dominated by an obvious reservation towards exactly what he has announced to give: an explicit narration of his religious experiences with the kýrios. That restraint extends to both his person and the kýrios. He twice underlines that he does not know about the physical status of the "man in Christ" so that there remains "confusion about his bodily status". ${ }^{29}$ He also twice ironically discloses that he is not allowed to report about those words that "the man in Christ" heard. Here he uses the twofold stylistic means of mystery and paradox (arrēta rēmata): of a revelation that prohibits revealing. ${ }^{30}$ In addition it remains unclear whether Paul refers to two different experiences, one raptus (harpagmós) to the "third heaven" and another raptus to the paradise, or whether the wording of V.4 is nothing but a stylistic variation of V.2. ${ }^{31}$ The text is deliberately unclear not only on this point, but also in regard to the most important aspect: does Paul actually report on optasías kai apokalýpseis kyríou? Heavenly journeys need not necessarily be linked to revelations or epiphanies of heavenly agents: in this context, of Christ. Scholars point to the lack of an explicit Christ epiphany in 2 Corinthians 12:1-5 (Thrall 2000, 773-775). Neither the rapture to the third heaven nor the rapture to the paradise seems to bring Paul to Christ or at least to the revelation of angels or patriarchs (cf. Luke 16:19-31). No vision is depicted at all, but only an enigmatic audition (ēkousa) - of whatever. Anyway, the dubious list of revelations comes to a premature end already with V.5, where Paul explicitly refuses to boast of his visions.

In V.6 Paul continues his self-commentary, developing a fresh argument: his refusal is not motivated by the weakness of his religious experiences. He states in contrast: these experiences are outsized and even overwhelming ( $t \bar{e}$ hyperbolē). When Paul declines to report about these visions (apocalýpseōn), it is in order to avoid what we would name personality-cult. He labels his rejection of religious self-praise as waiver (feídomai) and limits the importance of his person to his external appearance ("what is seen in me or heard from me"): a physical parody of the pneumatic visions and auditions.

29 Schantz 2009, 108. Colleen Shantz interprets this confusion as result of the neurobiological status of ecstasy in which Paul was during the raptus: "The disturbance of bodily perception is a telltale sign of ecstasy". Similar Thrall 2000, 782: Thrall speaks of an "ecstatic phenomenon of the displacement of the ego".

30 Shantz interprets the arrēta rēmata in the same line: "The detail of ineffability is far more intelligibly understood as the result of neural tuning than it has been as an awkward remnant of esotericism" (Shantz 2009, 108). If Shantz is right VV.2-4 must be taken seriously as records of an ecstatic state of Paul's mind and body.

31 See Thrall 2000, 791s. Thrall votes for "one single experience" (792). 
In V.7 Paul starts a second narration about a religious experience that underlines both the glory of his visions (about which he does not report) and the necessity and religious quality of his disease. Hans Dieter Betz has interpreted VV.7-10 as a parody of a Christ-aretology: „Formgeschichtlich gesehen haben wir in V.7-10 ein ,Heilungswunder' vor uns, das im Stile einer Aretalogie vorgetragen ist“ (Betz 1969, 289). Betz analyzes the structure of the text-unit: prayer - oracle - boast (an aretology, though not of the healing God, but of Paul himself). ${ }^{32}$ He refers to the Asclepius-inscriptions from Epidaurus. Betz's famous classification affects the whole text and calls into question whether Paul records actual experiences at all. Scholars such as Margaret E. Thrall, who wrote the outstanding commentary on 2 Corinthians, and Thomas Schmeller, the author of a comprehensive commentary from 2016, criticize Betz's doubts by pointing to the fact that Paul speaks of optasías kai apokalýpseis kyriou, a phrase that can hardly be interpreted as parody. Thrall therefore states: "What we have here will be a serious account of real religious experience, and, as the exegesis will show, experience personal to Paul” (Thrall 2000, 777s). I follow Thrall in regard to 12:1-10, but take into consideration Betz's literary approach to VV.7-9, especially in regard to the Asclepius-cult. ${ }^{33}$

Perhaps the description of this sub-unit as "parodistic audition" would better match the structure of the text, because the logion kyriou is the point of the brief narration, not the - refused - healing miracle of the God (kýrios). Let us have a look at the details of the text in question. First, Paul reports a severe disease and interprets the disease as caused by a satanic figure. For depicting his disease as gravely as possible, he combines three elements: first, the violent metaphor of skólops ${ }^{34}$ tè sarkí; second, the evil, i.e. destructive heavenly agent: the ággelos satanā; and third, a second metaphor of the angel's violent striking of Paul's face (kolafize) $)$. In V.8 even a fourth aspect is added: Paul understands the attacks of physical pain as caused by the angel of Satan, i.e. as actual assaults, not only as an interior state of feeling weak or ill. This combination is most remarkable: no angel is mentioned in the context of the heavenly world of VV.1-4, as Paul's addressees most likely may have expected, but when it comes to Paul's physical existence and to his illness, he introduces an "evil angel”! Scholars have discussed to which kind of disease Paul alludes, or what he veils

32 This is the reason for Betz's labelling the text as parody.

33 In that regard Aelius Aristides' Hieroi Logoi are of interest. Aristides praises his God Asclepius for his healing power. Though Aristides in some respects always remains physically weak, he thanks Asclepius for protecting him. In contrast, Paul's kyrios explicitly refuses help. 34 Pale or thorn, Liddell Scott 1613. Heckel 1993, 84. 
behind the metaphor of the "thorn in the flesh". ${ }^{35}$ Since Paul deliberately hides the exact information about his disease, ${ }^{36}$ the conundrum of Paul's illness will remain unsolved. The only thing we know is that he also mentions a state of physical weakness in his letter to the Galatians (4:12-15):

12 Friends, I beg you, become as I am, for I also have become as you are. You have done me no wrong. 13 You know that it was because of a physical infirmity (asthéneian tēs sarkós) that I first announced the gospel to you; 14 though my condition put you to the test, you did not scorn or despise me, but welcomed me as an angel of God (ággelon theou ), as Christ Jesus. 15 What has become of the goodwill you felt? For I testify that, had it been possible, you would have torn out (exorýxantes) ${ }^{37}$ your eyes and given them to me.

Also in this text Paul on the one hand uses a metaphor of physical brutality (V.15) and contraposes physical disgust and contempt to the metaphorically alluded heavenly world of angels and of Christ on the other. In Galatians 4:13-14, Paul demonstrates how violently he can speak about his own body (sárx, flesh) from the material point of view and to what degree his physical state matters for the communities. In Galatians 4:14 he interprets his person by using a counter-realistic metaphorical wording for the description of his weak body.

Back to 2 Corinthians. In VV 8-9 Paul refers to a different kind of revelation: an audition as the result of a prayer for healing that remained unanswered (cf. Wischmeyer 2004). The account of the second audition is antithetic to the first heavenly audition in V.4. This time, the wording of the logos kyriou is carefully communicated by Paul. The scenario is opened up by a formal three-time prayer to the kýrios: a ceremonious or ritual setting of private prayer. ${ }^{38}$ The lógos is initiated by a disclosure formula. The answer in V.9a is perfectly styled: ${ }^{39}$ the first sentence works as oracle, the second sentence gives the reason. Stylistic means are: brevitas or laconism, chiasm, antithesis, obscurity, paradox.

In VV.9b and 10 Paul draws the conclusion of the logion: the heavenly dýnamis of Christ dwells (episkēnōsē) in his feeble or sick body, and accordingly his aretē or kaúchèma concerns his physical, not his pneumatic state. He confirms his conclusion by enumerating his peristáseis - a hardships-list. The closure-formula of the text consists of a repetition of the logos kyriou, related to his person (ego-document).

35 Thrall 2000, 809-818. Thrall opts for migraine.

36 Perhaps the Corinthians knew about the particular illness. Betz 1969, 290: „Stilgerecht spricht der Apostel über sein Leiden in mythischen und metaphorischen Wendungen.“ Most likely we may suppose a kind of violent headache or migraine.

37 Exorýssō, to dig out, to gouge out: Liddell Scott 598.

38 See Jesus' private prayer in Luke 22:39-49.

39 Betz 1969 pass. See Aelius Aristides, Hieroi Logoi I 71. 
This brief description of what we find in the text makes clear both that 2 Corinthians 12:1-10 is neatly composed by different small text-units that use specific sub-genres, and that these sub-texts, read as one coherent narrative, belong to the genre of a counter-revelation. Therefore the text cannot simply be read as the outcome of Paul's personal experiences, since Paul has molded these experiences into a deliberately composed pasticcio of small pieces of religious genres with the overall intention of foiling the Corinthians' claim for stories about revelations. What we read is by no means an unfiltered record or minute of several revelations in the form of one or two visions and an audition, but a literary text, composed with the intention of rebuking and correcting the Corinthians who long for narrations of Paul's personal religious experience, i.e. of heavenly encounters comparable to those recorded by Paul's opponents (2 Cor 11:5-33). This is also true when we basically agree with Colleen Shantz who argues in favor of interpreting our text as a report on an actual ecstatic experience. ${ }^{40}$

\section{Results}

We started our enquiry with the expectation that those texts Paul has written about his personal revelations can be interpreted as examples of his religious experience and fall within the field of private or individual religion. At the end of the exegesis two conclusions emerge: first, there is an obvious lack of narration of visions, revelations and auditions. With the introductory passage - "I will go on to visions and revelations (optasias kai apokalýpseis kyriou) of the Lord" - Paul raises and then almost immediately definitely disappoints the Corinthians' expectations: he claims that he has had exceptional revelations, but does not narrate any details. Second, he points to a new field of religious experience: not the heavens, but his own body. This turn from heaven to Paul's body is authorized by the kýrios, and hence Paul himself, his body (sōma) and his flesh (sárx) become the place of this kind of revelation, not the third heaven and not the paradise, as the Corinthians believed. In terms of personal religion, not visions of the heavenly world, but the material body, with its status of disease and hardships, is the place where that religion, understood as communication with the heavenly kýrios, is experienced according to Paul.

By that Paul opens up a space of religious experience that will be of increasing importance during the following centuries. This may be illustrated by a very brief look on the history of reception of Paul's turn to his physical body

40 Cf. the positions of M. Thrall and Th. Schmeller. 
as a religious place and as a bearer of revelation. Paul's turn leads to the concepts of early Christian martyrdom (Acta Pauli) as well as to the earliest development of Christian monasticism. But also Heaven and Paradise as the most favored places of revelations retained their importance, as is illustrated by the Apocalypse of Paul and related texts. Finally, Paul's interpreting his body as a religious place is not far from the ancient Jewish concept of martyrdom as elaborated in 4 Maccabees. ${ }^{41}$ Here the body of the martyr is the place of the demonstration of aretē and of eusébeia in order to demonstrate the divine laws (theías nomothesías). ${ }^{42}$

When we ask for the outcome of the exegesis for the issue of religious experience, we are relegated to a deliberately styled text, not to the possible experience itself. Paul's emphasis is not on heavenly visions and mysterious words, on physical ecstasy of his body or mind, or on his own affects, but on his feeble body, on pain, and on a saying of the Lord that is very disappointing. What he wants to establish by his text is control of any kind of religious experience. The benchmark is the waiver of "boasting" of ecstatic experiences. It seems as if Paul wants to strictly confine those personal experiences he had undoubtedly gained to the private sphere. The context for the topic of religious experience is the fight over authority in the communities, and the means of communication are his letters. His opponents apprehended these letters as "heavy and impressive" weapons in comparison to his physical performance which is "weak and rhetorically miserable" (2 Corinthians 10:10). So finally the opponents lead us back to the letters, i.e. to the texts that enshrine both Paul's religious experiences and their critical domestication.

\section{Bibliography}

\section{Sources}

Aelius Aristides. Heilige Berichte, ed. and transl. H.O. Schröder. Heidelberg 1986. Aelius Aristides. In Praise of Asclepius. Selected Prose Hymns, intr., ed. and transl. Michael Trapp, Donald A. Russel, Heinz-Günther Nesselrath. SAPERE XXIX. Tübingen 2016.

41 Scholars date 4 Macc between the end of the 1st and the first half of the 2nd century CE (earlier options also possible).

424 Macc 17:7.12.16. 


\section{Literature}

Betz, Hans Dieter 1969. 'Eine Christus-Aretalogie bei Paulus', ZThK 66. 288-305.

Betz, Hans Dieter (ed.) 1978. Plutarch's Ethical Writings and Early Christian Literature. SCH 4. Leiden.

Betz, Hans Dieter 1990-2009. Gesammelte Aufsätze I-V. Tübingen.

Bieringer, Reimund (ed.) 1996. The Corinthian Correspondence. BETL 125. Leuven.

Downing, F.Gerald 1998. Cynics, Paul and the Pauline Churches. London/New York.

Engberg-Pedersen, Troels 2000. Paul and the Stoics. Edinburgh.

Engberg-Pedersen, Troels 2010. Cosmology and Self in the Apostle Paul: The Material Spirit. Oxford.

Heath, Jane M.F. 2013. Paul's Visual Piety: The Metamorphosis of the Beholder. Oxford.

Heckel, Ulrich 1993. 'Der Dorn im Fleisch: Die Krankheit des Paulus in 2. Kor 2,7 und Gal 4,13ff', ZNW 84. 65-92.

Heininger, Bernhard 1996. Paulus als Visionär. HBS 9. Freiburg.

Horsley, Richard E. (ed.) 1997. Paul and Empire: Religion and Power in Roman Imperial Society. Edinburgh.

Horsley, Richard E. (ed.) 2000. Paul and Politics: Ecclesia, Imperium, Israel, Interpretation. London.

van Kooten, George; Wischmeyer, Oda; Wright, N.T. 2015. 'How Greek was Paul's Eschatology?', NTS 61. 245-249.

Klauck, Hans-Josef 2003. The Religious Context of Early Christianity: A Guide to Graeco-Roman Religions. Philadephia.

Lang, Manfred 2013. 'Impulse aus der Religionsgeschichte.' In Paulus Handbuch, ed. Friedrich W. Horn. Tübingen. 40-41.

Malherbe, Abraham J. 2006. Paul and the Popular Philosophers. Minneapolis.

Malherbe, Abraham J. 2014. Light from the Gentiles: Hellenistic Philosophy and Early Christianity: Collected Essays 1959-2012. SuppINT 150. Leiden.

Meier, Hans-Christoph 1998. Mystik bei Paulus. TANZ 26. Tübingen/Basel.

Öhler, Markus 2016. 'Meeting at Home: Greco-Roman Associations and Pauline Communities.' In Scribal Practices and Social Structures among Jesus Adherents. Essays in Honour of John S. Kloppenborg, ed. William E. Arnal, Richard S. Ascough, Robert A. Derrenbacker, Philip A. Harland. BEThL 285. Leuven. 517-545.

Paynter, Maximilian 2017. Das Evangelium des Paulus. NET 24. Tübingen/Basel.

Rowland, Christopher; Morray-Jones, C.R.A. 2009. The Mystery of God. Early Jewish Mysticsm and the New Testament. CRINT 12. Leiden.

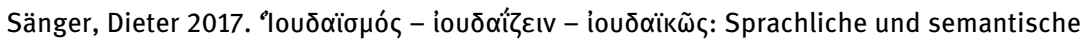
Überlegungen im Blick auf Gal 1,13f. und 2,14', ZNW 108. 150-185.

Shantz, Colleen 2009. Paul in Ecstasy: The Neurobiology of the Apostle's Life and Thought. Cambridge.

Schmeller, Thomas 2015. Der Zweite Brief an die Korinther (2Kor 7,5-13,13). EKK VIII/2. Neukirchen-Vluyn.

Stowers, Stanley. 2015. 'Paul and the Terrain of Philosophy', Early Christianity 6. 141-165.

Theissen, Gerd 2007. Die Entstehung des Neuen Testaments als literaturgeschichtliches Problem. Phil.-Hist Kl. HAW 40. Heidelberg. 
Thrall, Margaret E. 2000. The Second Epistle to the Corinthians vol. II. Commentary on Second Corinthians VII-XIII, ICC. Edinburgh.

Treu, Nadine 2018. Das Sprachverständnis des Paulus im Rahmen des antiken Sprachdiskurses. NET 26. Tübingen.

Winger, Michael. 2017. 'Paul and egō: Some Comments on Grammar and Style', NTS 63. 23-37. Wischmeyer, Oda 2001. '2 Korinther 12,1-10: Ein autobiographisch-theologischer Text des

Paulus.' In Was ist ein Text? ed. Oda Wischmeyer, Eve Marie Becker. Tübingen/Basel. 29-41. Wischmeyer, Oda 2004. '2Kor 12,7-8: Ein Gebet des Paulus.' In Prayer from Tobit to Qumran, ed. Renate Egger-Wenzel, Jeremy Corley. Berlin. 467-479.

Wischmeyer, Oda 2005. 'Paulus als Ich-Erzähler: Ein Beitrag zu seiner Person, seiner Biographie und seiner Theologie.' In Biographie und Persönlichkeit des Paulus, ed. EveMarie Becker, Peter Pilhofer. WUNT 187. Tübingen. 88-105.

Wischmeyer, Oda 2018. 'Paul and the Concept of the Homo Novus.' In Paul as Homo Novus: Authorial Strategies of Self-Fashioning in Light of a Ciceronian Term, ed. Eve-Marie Becker, Jacob Mortensen. Göttingen. 55-70.

Zeller, Dieter 2010. Der erste Brief an die Korinther. KEK 5. Göttingen. 